Supporting Information for:

\title{
Construction of A Rational-designed Multifunctional \\ Platform Based on Fluorescence Resonance Energy Transfer \\ Process for Simultaneous Detection of $\mathrm{pH}$ and Endogenous \\ Peroxynitrite
}

Luo Bao, Keyin Liu*, Yunling Chen, Guihua Yang*

State Key Laboratory of Biobased Material and Green Papermaking, Key Laboratory of Pulp \& Paper Science and Technology of Shandong Province/Ministry of Education, Qilu University of Technology, Shandong Academy of Sciences, Jinan, China, 250353.

*Corresponding authors:

E-mail: keyinliu@163.com (K. Liu);ygh2626@126.com (G. Yang)

List of Contents: $\quad$ Page

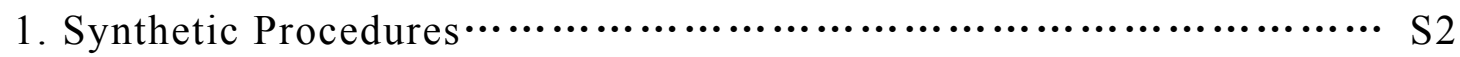

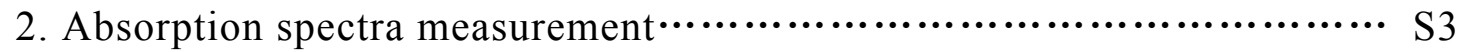

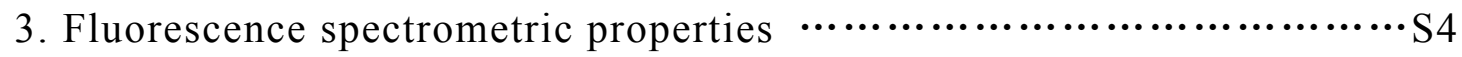

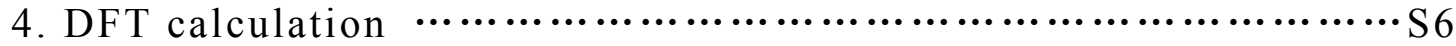

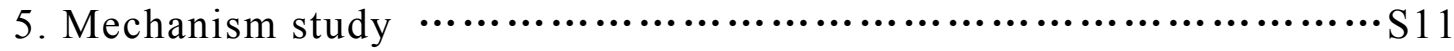

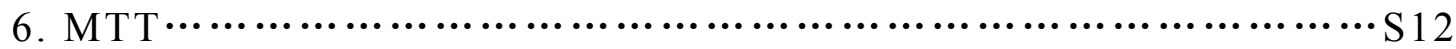

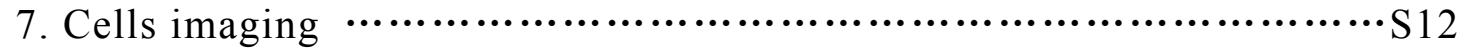

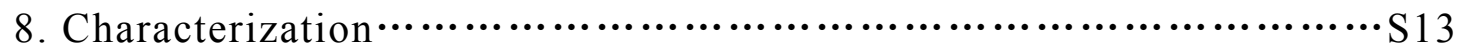

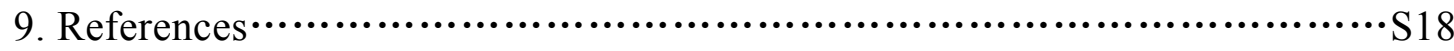




\section{Synthesis of RN-NA}

Synthesis of compound 2. Here, 6-bromo-1H,3H-benzo[de]isochromene-1,3-dione (1.37 g, $4.96 \mathrm{mmol})$ and propargyl amine $(0.33 \mathrm{~g}, 6.00 \mathrm{mmol})$ were reacted overnight in ethanol at $80^{\circ} \mathrm{C}$ (Scheme 2). The reaction process was detected by TLC. The crude product was separated and purified via column chromatography, and compound 1 (1.05 g, $3.36 \mathrm{mmol}$ ) was obtained as white solid with 67\% yield. Then compound 1 (0.63 g, 2.00 mmol) continued to react with $N$-(2-aminoethyl) morpholine $(0.31 \mathrm{~g}, 2.40 \mathrm{mmol})$ in ethylene glycol monomethyl ether at $110^{\circ} \mathrm{C}$ overnight. The reaction process was monitored via TLC. The final product was separated and purified via column chromatography to obtain compound $\mathbf{2}(0.39 \mathrm{~g}, 1.08 \mathrm{mmol})$ as yellow solid, with $54 \%$ yield. The NMR data are as follows: ${ }^{1} \mathrm{H}$ NMR $\left(400 \mathrm{MHz}, \mathrm{CDCl}_{3}\right) \delta 8.58(\mathrm{~d}, J=7.3 \mathrm{~Hz}, 1 \mathrm{H}), 8.44$ $(\mathrm{d}, J=8.4 \mathrm{~Hz}, 1 \mathrm{H}), 8.06(\mathrm{~s}, 1 \mathrm{H}), 7.61$ (t, $J=7.4 \mathrm{~Hz}, 1 \mathrm{H}), 6.61(\mathrm{~d}, J=8.1 \mathrm{~Hz}, 1 \mathrm{H}), 6.28(\mathrm{~s}, 1 \mathrm{H}), 4.89(\mathrm{~d}, J=$ $2.2 \mathrm{~Hz}, 2 \mathrm{H}), 3.73(\mathrm{~m}, 4 \mathrm{H}), 3.37$ (d, $J=13.5 \mathrm{~Hz}, 2 \mathrm{H}), 2.78(\mathrm{~m}, 2 \mathrm{H}), 2.52(\mathrm{~m}, 4 \mathrm{H}), 2.10(\mathrm{~s}, 1 \mathrm{H}) .{ }^{13} \mathrm{C} \mathrm{NMR}(100$ $\left.\mathrm{MHz}, \mathrm{CDCl}_{3}\right) \delta 164.02,149.73,135.02,131.57,129.95,126.42,124.90,124.89,120.48,116.00,104.61,79.17$, 69.92, 67.04, 59.80, 55.99, 53.13, 38.85, 29.09. High-resolution mass spectra (HRMS) (electrospray ionization [ESI]) $\mathrm{m} / \mathrm{z}$ calcd. for $\mathrm{C}_{21} \mathrm{H}_{21} \mathrm{~N}_{3} \mathrm{O}_{3}[\mathrm{M}+\mathrm{H}]^{+}: 364.1611$. Found: 364.1649 .

Synthesis of compound 4. First, 2-(4-(diethylamino)-2-hydroxybenzoyl) benzoic acid (2.69 g, $10.0 \mathrm{mmol})$ and cyclohexanone $(1.47 \mathrm{~g}, 15.0 \mathrm{mmol})$ were added to $20 \mathrm{~mL}$ concentrated sulfuric acid $(98 \%)$ at $0^{\circ} \mathrm{C}$, and the mixture was heated and refluxed at $90^{\circ} \mathrm{C}$ for $4 \mathrm{~h}$. The reaction progress was detected via TLC. The mixture was cooled to room temperature and slowly poured into $200 \mathrm{~g}$ crushed ice. The crude product was separated via filtration and further purified via column chromatography. Compound 3 ( $2.80 \mathrm{~g}, 7.80 \mathrm{mmol}$ ) was finally obtained as red solid with 78\% yield. Compound $3(1.13 \mathrm{~g}, 3.0 \mathrm{mmol})$ and 4-azidobenzaldehyde $(0.46 \mathrm{~g}, 3.10$ mmol) were refluxed and condensed in $50 \mathrm{~mL}$ glacial acetic acid at $90^{\circ} \mathrm{C}$ overnight. The reaction mixture was detected via TLC, and the crude product was purified via column chromatography to obtain compound 4 (1.24 g, $2.46 \mathrm{mmol}$ ) with $82 \%$ yield. The NMR data are as follows: ${ }^{1} \mathrm{H}$ NMR $\left(400 \mathrm{MHz}, \mathrm{DMSO}-\mathrm{d}_{6}\right) \delta 7.94(\mathrm{~d}, J=$ $7.6 \mathrm{~Hz}, 1 \mathrm{H}), 7.80(\mathrm{t}, J=7.5 \mathrm{~Hz}, 1 \mathrm{H}), 7.68(\mathrm{t}, J=7.5 \mathrm{~Hz}, 1 \mathrm{H}), 7.51(\mathrm{~d}, J=8.5 \mathrm{~Hz}, 2 \mathrm{H}), 7.37$ (s, 1H), 7.33 (d, $J=7.7 \mathrm{~Hz}, 1 \mathrm{H}), 7.17(\mathrm{~d}, J=8.6 \mathrm{~Hz}, 2 \mathrm{H}), 6.53(\mathrm{~d}, J=2.4 \mathrm{~Hz}, 1 \mathrm{H}), 6.44(\mathrm{dd}, J=9.0,2.5 \mathrm{~Hz}, 1 \mathrm{H}), 6.38(\mathrm{~d}, J=$ $8.9 \mathrm{~Hz}, 1 \mathrm{H}), 3.35(\mathrm{~s}, 4 \mathrm{H}), 2.51-2.50(\mathrm{~m}, 2 \mathrm{H}), 1.57(\mathrm{~m}, 1 \mathrm{H}), 1.54(\mathrm{~m}, 3 \mathrm{H}), 1.09(\mathrm{t}, J=7.0 \mathrm{~Hz}, 6 \mathrm{H}) .{ }^{13} \mathrm{C} \mathrm{NMR}$ $\left(101 \mathrm{MHz}, \mathrm{CDCl}_{3}\right) \delta 212.74,175.28,169.90,166.60,161.79,155.90,151.84,150.43,143.60,138.67,134.40$, $134.00,131.02,130.57,130.55,129.35,129.30,128.65,123.65,123.64,122.58,118.85,101.15,97.17,47.75$, 44.51, 29.72, 27.17, 23.14, 22.29, 12.47. HRMS (ESI) m/z calcd. for $\mathrm{C}_{31} \mathrm{H}_{29} \mathrm{~N}_{4} \mathrm{O}_{3}[\mathrm{M}]^{+}:$: 505.2235. Found: 505.2230 .

Synthesis of RN-NA. Compound $2(0.12 \mathrm{~g}, 0.24 \mathrm{mmol})$ and compound $4(0.11 \mathrm{~g}, 0.25 \mathrm{mmol})$ were dissolved in $18 \mathrm{ml} \mathrm{DMSO}$, and then $8.0 \mathrm{mg}$ sodium ascorbate was added. The mixture was stirred, and $2 \mathrm{ml}$ of copper sulfate aqueous solution $(1 \mathrm{mg} / \mathrm{ml})$ was added, protected by nitrogen, and reacted at $35^{\circ} \mathrm{C}$ for $24 \mathrm{~h}$. The reaction mixture was detected via TLC, and the crude product was purified via column chromatography to obtain compound RN-NA $(0.15 \mathrm{~g}, 0.18 \mathrm{mmol})$ with $75 \%$ yield. The product was stored at $2{ }^{\circ} \mathrm{C}-8^{\circ} \mathrm{C}$ in the refrigerator for use. The NMR data are as follows: ${ }^{1} \mathrm{H}$ NMR $\left(400 \mathrm{MHz}, \mathrm{MeOD}-\mathrm{d}_{3}\right) \delta 8.30(\mathrm{~s}, 2 \mathrm{H}), 7.99(\mathrm{~s}, 2 \mathrm{H})$, 7.75-7.65 (m, 1H), 7.52 (d, J=6.5 Hz, 1H), 7.34 (d, J=7.2 Hz, 4H), $7.21(\mathrm{~d}, J=14.1 \mathrm{~Hz}, 2 \mathrm{H}), 6.93(\mathrm{~d}, \mathrm{~J}=$ $9.3 \mathrm{~Hz}, 1 \mathrm{H}), 6.69(\mathrm{~s}, 1 \mathrm{H}), 6.31(\mathrm{~s}, 1 \mathrm{H}), 6.21(\mathrm{~d}, J=14.2 \mathrm{~Hz}, 2 \mathrm{H}), 4.14(\mathrm{~d}, J=7.2 \mathrm{~Hz}, 4 \mathrm{H}), 3.57(\mathrm{~d}, J=7.0 \mathrm{~Hz}$, 4H), $3.34(\mathrm{~m}, 4 \mathrm{H}), 2.84(\mathrm{~s}, 4 \mathrm{H}), 2.71(\mathrm{~m}, 2 \mathrm{H}), 2.16(\mathrm{~m}, 2 \mathrm{H}), 1.84-1.44(\mathrm{~m}, 4 \mathrm{H}), 1.18-0.73(\mathrm{~m}, 4 \mathrm{H}) .{ }^{13} \mathrm{C}$ NMR $\left(101 \mathrm{MHz}, \mathrm{CDCl}_{3}\right) \delta 170.06,167.37,164.48,163.78,156.16,152.53,152.19,149.67,149.40,145.00,137.68$, $137.22,135.56,134.88,134.49,131.76,131.50,131.48,130.59,130.56,129.95,129.26,128.52,128.33$, $128.14,127.63,126.34,124.96,124.83,123.79,123.47,122.93,121.35,120.46,120.23,110.04,108.84$, 


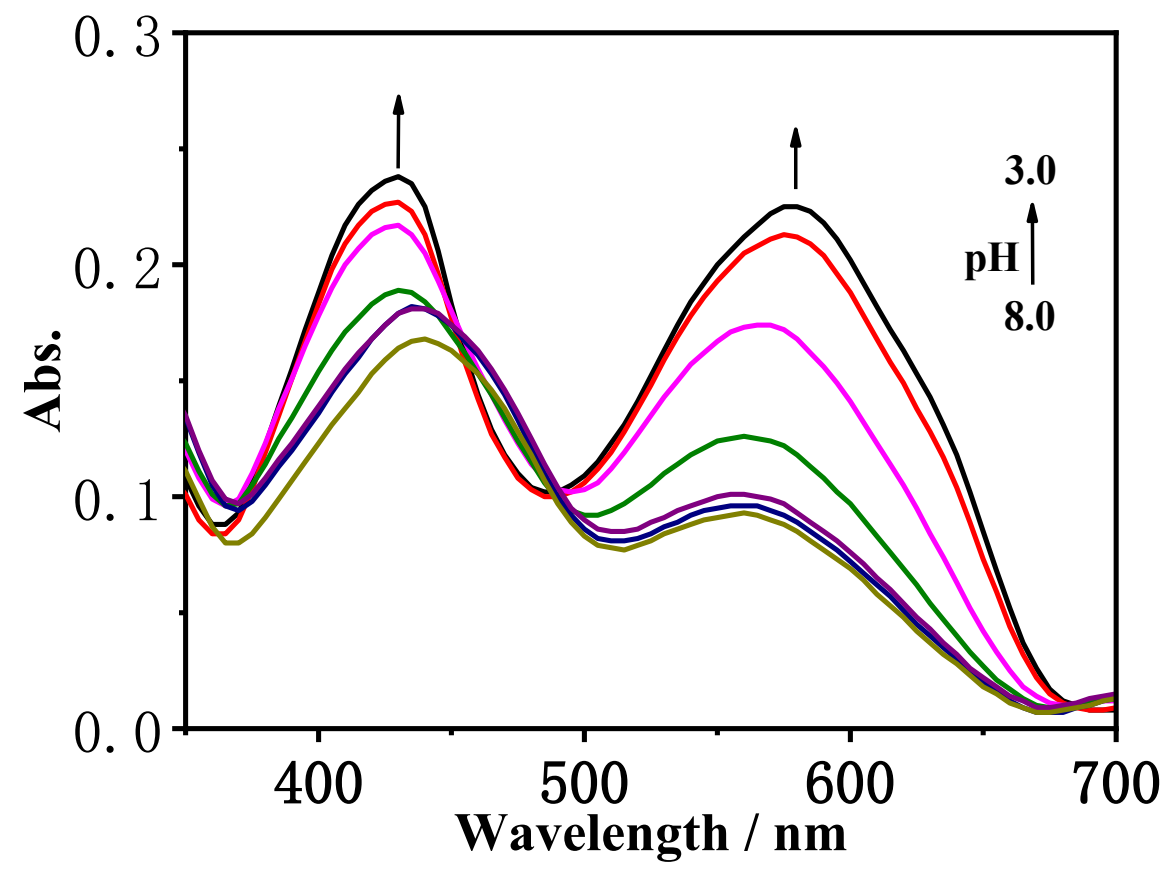

Figure S1 The absorption spectra change of RN-NA in different $\mathrm{pH}$ values solution. $10 \mu \mathrm{M}$ of RN-NA in $10 \mathrm{mM}$ of PBS with $5 \%$ DMSO as cosolvent.

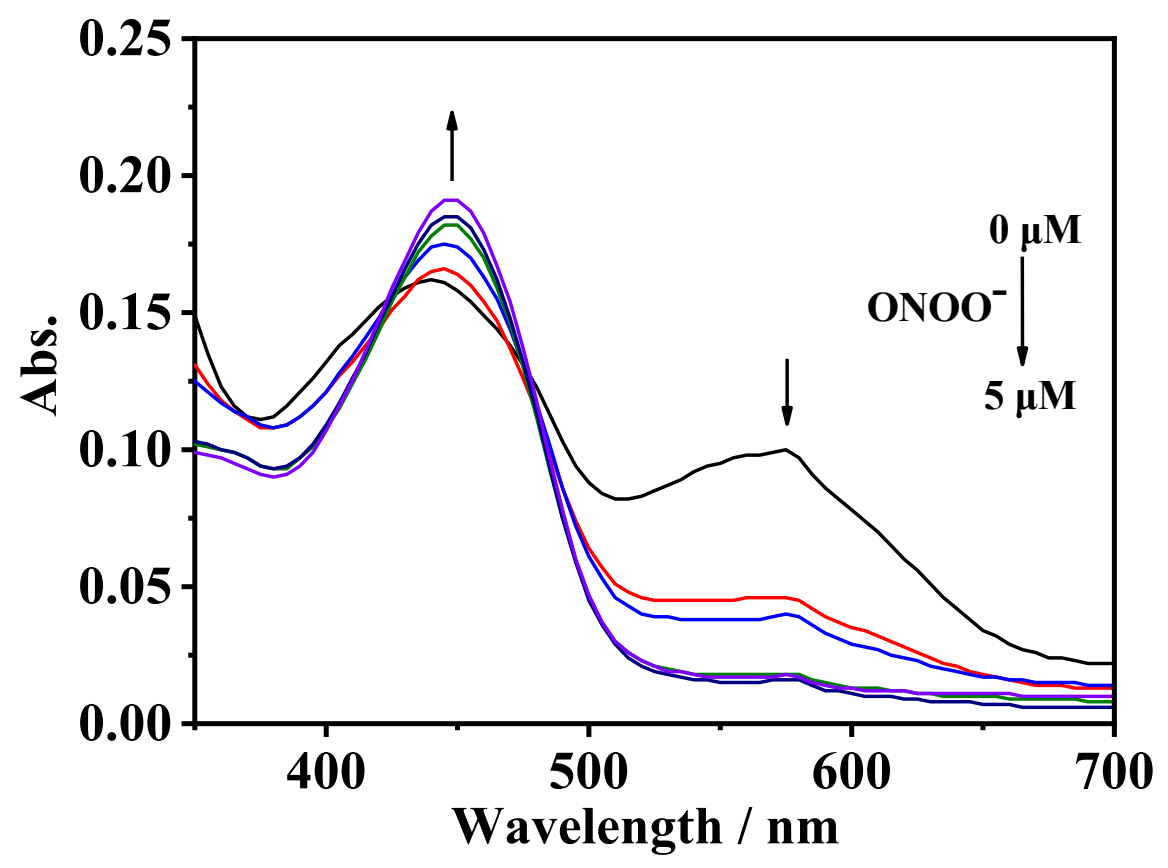

Figure S2 The absorption spectra change of RN-NA with increase concentrations of 
ONOO-

(a)

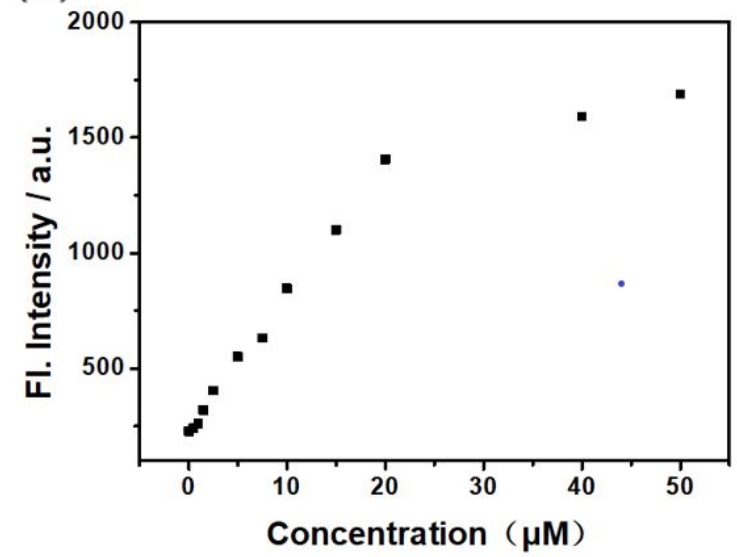

(b)

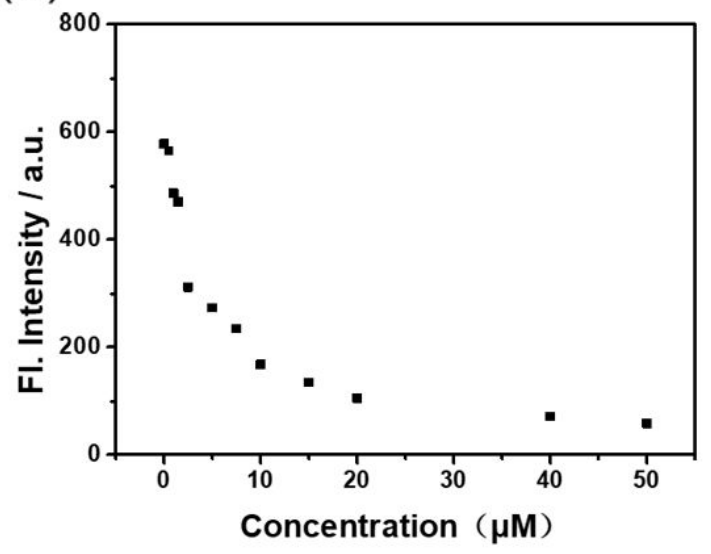

Figure S3 Fluorescence spectrometric properties of RN-NA under SIN-1 titration. (a) The fluorescence intensity of $10 \mu \mathrm{M} \mathbf{R N}-\mathbf{N A}$ at $545 \mathrm{~nm}$ was measured by increasing the concentration of SIN-1. Ex=400 nm. (b) The fluorescence intensity of $10 \mu \mathrm{M} \mathbf{R N}$ NA at $710 \mathrm{~nm}$ was measured by increasing the concentration of SIN-1. Ex $=580 \mathrm{~nm}$.
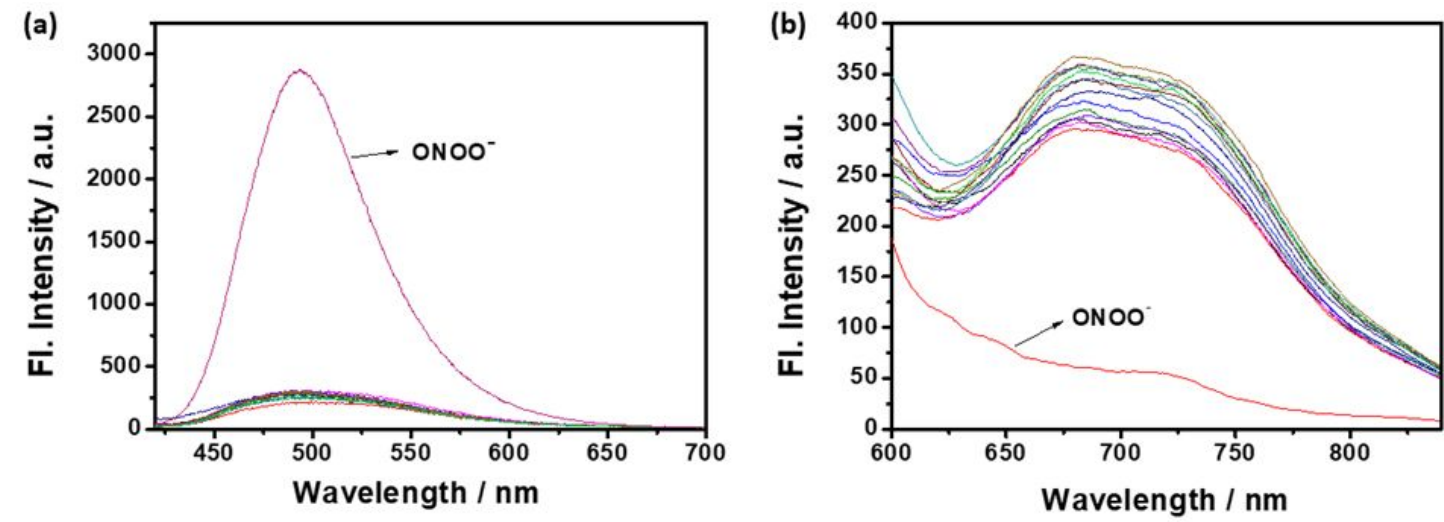

Figure S4 Fluorescence intensity change of RN-NA in various interferences. $10 \mu \mathrm{M}$ of RN-NA in PBS (pH 7.4) with $50 \mu \mathrm{M}$ of small molecules, such as Glu, Cys, $\mathrm{S}_{2} \mathrm{O}_{3}{ }^{2-}, \mathrm{S}^{2-}$, $\mathrm{SO}_{3}{ }^{2-}, \mathrm{HSO}_{3}{ }^{-}, \mathrm{NO}_{2}{ }^{-}, \mathrm{H}_{2} \mathrm{O}_{2}, \mathrm{ClO}^{-}, \cdot \mathrm{OH}, \mathrm{Vc}^{-}, \mathrm{Zn}^{2+}, \mathrm{Fe}^{3+}, \mathrm{O}^{2-}$, and $\mathrm{ONOO}^{-}$, respectively. (a) $\lambda \mathrm{ex}=400 \mathrm{~nm}$ and (b) $\lambda \mathrm{ex}=580 \mathrm{~nm}$. 


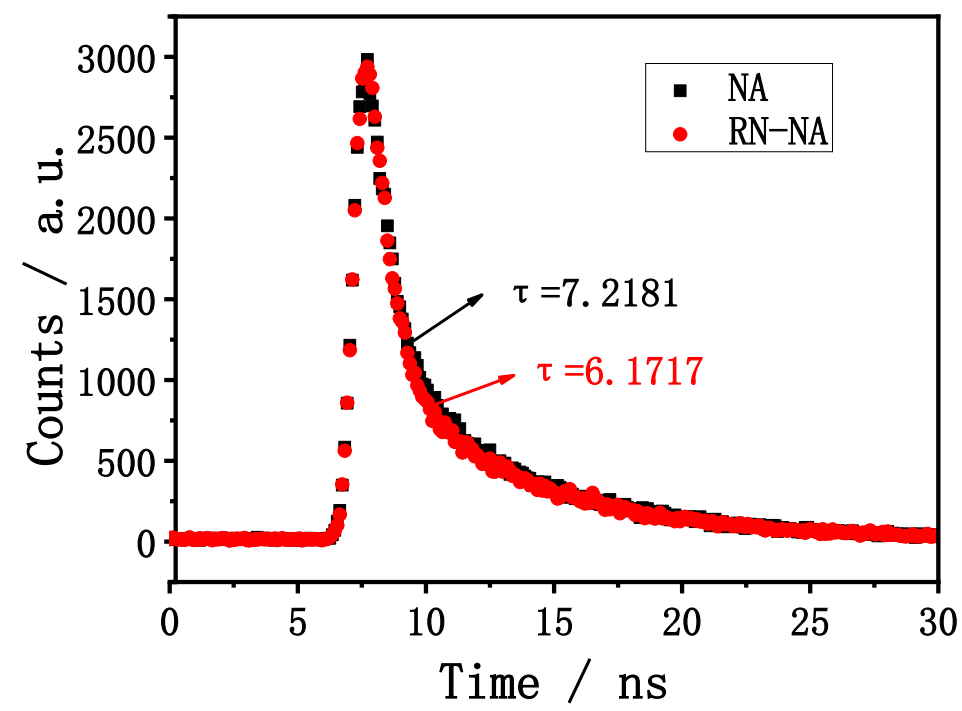

Figure S5 Fluorescence lifetime measurement of RN-NA and NA. $10 \mu \mathrm{M}$ of RN-NA and NA in PBS solution were measured by $488 \mathrm{~nm}$ excitation and collected at $550 \mathrm{~nm}$, respectively.

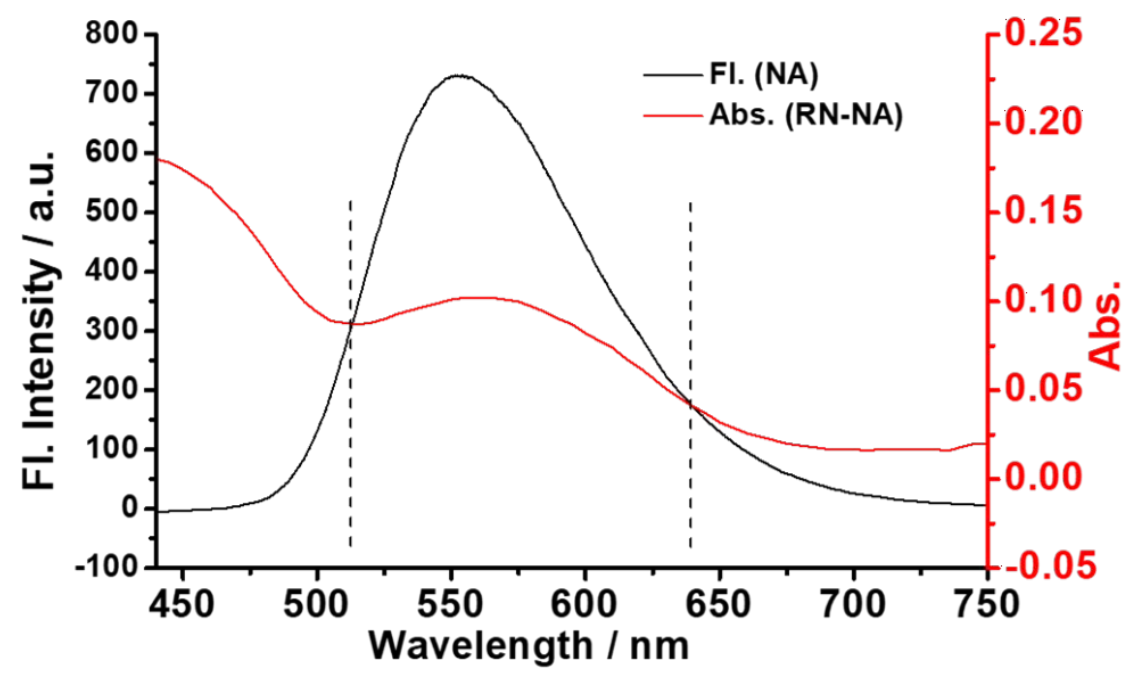

Figure S6 The overlap spectra of the emission of NA and the absorption of RN-NA in pH 7.0 solution. 


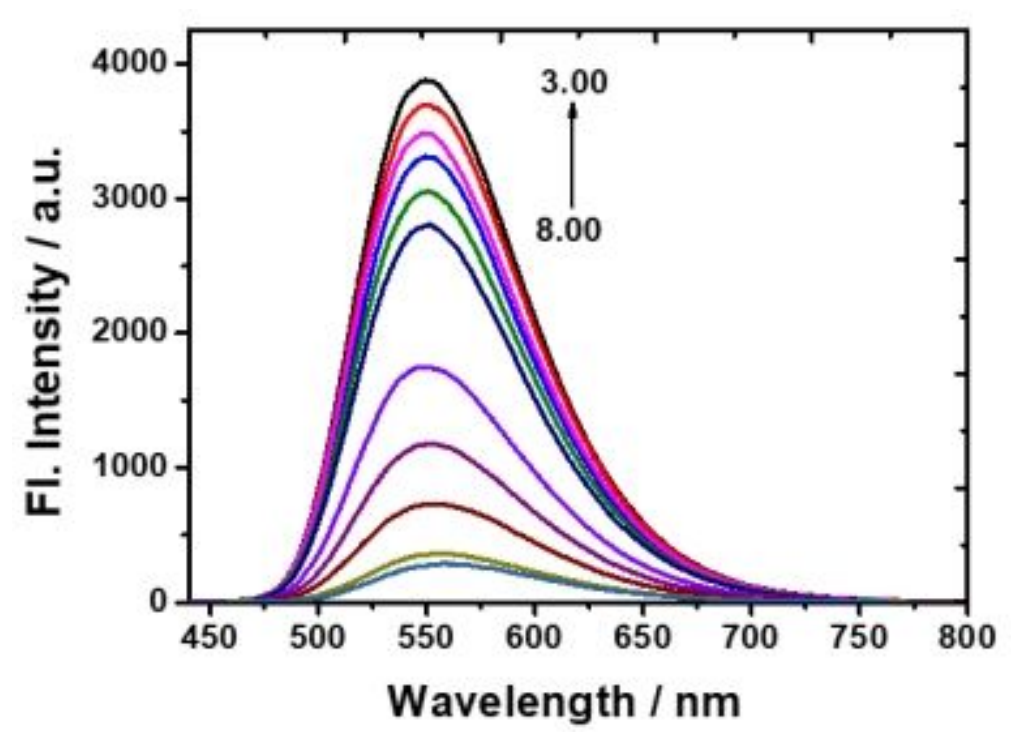

Figure S7 Fluorescence spectra changes of NA in buffer with different $\mathrm{pH}$ values. Fluorescence spectra changes of $10 \mu \mathrm{M}$ NA in PBS solutions (10 mM, with 5\% DMSO) with different $\mathrm{pH}$ values: $\lambda \mathrm{ex}=420 \mathrm{~nm}$.

\section{DFT calculation}

To study the fluorescence spectra change, RN-NA was divided into two parts, namely RN and NA, and their Protonated product, RN-H and NA-H. All the compound was used for DFT calculation by Gaussian16, B3LYP, 6-311G(d) and DFT-D3(BJ) mode. The optimized configuration of all the compounds and the Highest Occupied Molecular Orbital (HOMO), Lowest Unoccupied Molecular Orbital (LUMO), and orbitals energy were shown in Figure S8-S10 and Table S1, S2. As indicated by calculation result, the calculated excitation energy of $\mathbf{R N}-\mathbf{H}$ and $\mathbf{R N}$ are located at $683.64 \mathrm{~nm}$ and $711.27 \mathrm{~nm}$, respectively. 


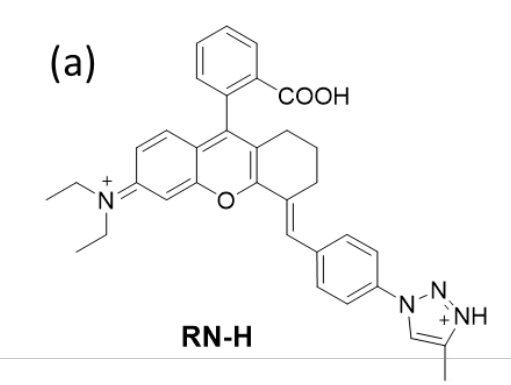

(c)

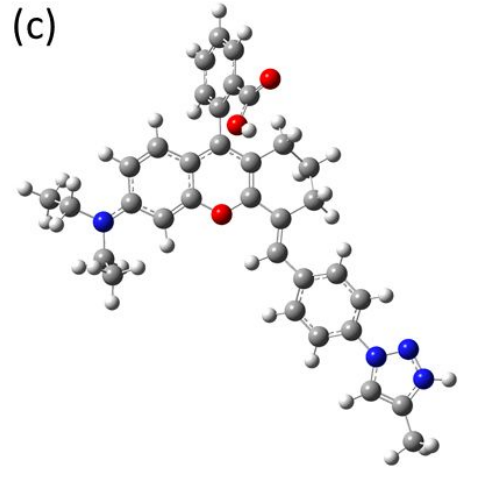

(b)

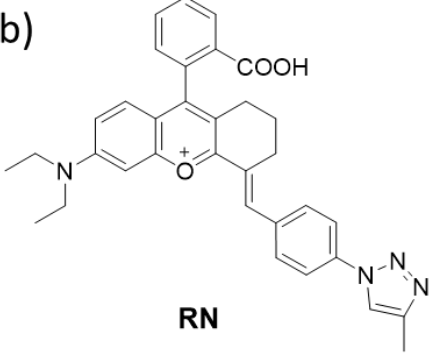

(d)

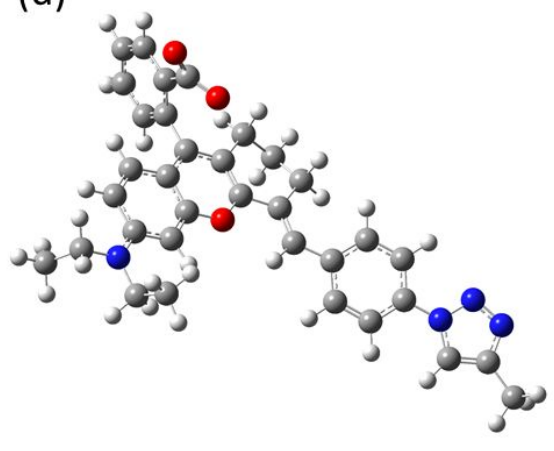

Figure S8 (a, b) The chemical structure of RN-H and RN, (c, d) the optimized configuration of RN-H and $\mathbf{R N}$ by Gaussian16, B3LYP, 6-311G(d).

(a)
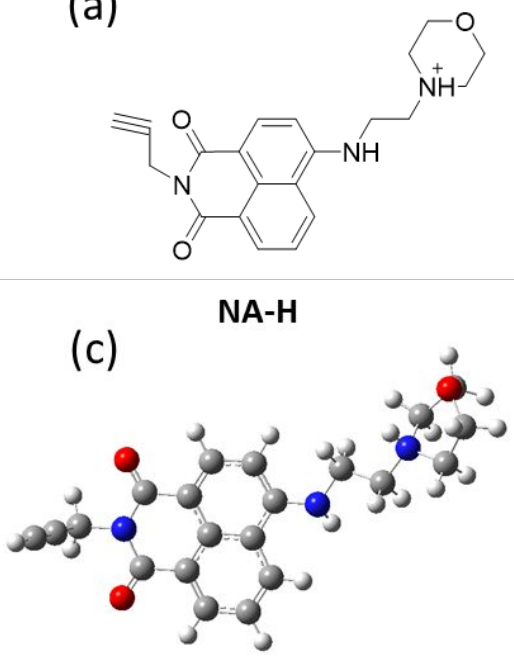

(b)

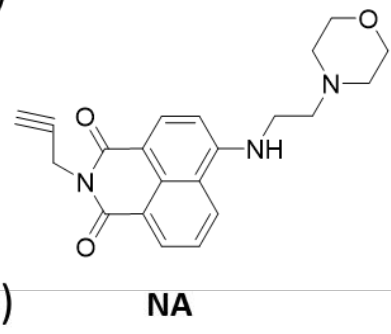

(d)

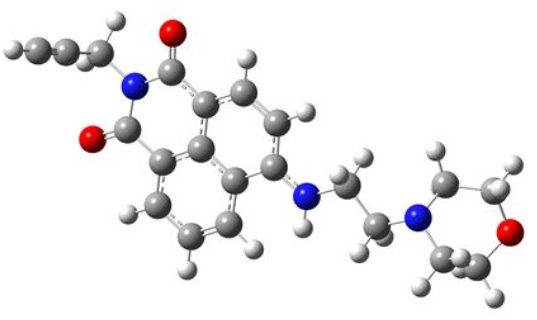

Figure S9 (a, b) The chemical structure of NA-H and NA, (c, d) the optimized configuration of NA-H and NA by Gaussian16, B3LYP, 6-311G(d). 

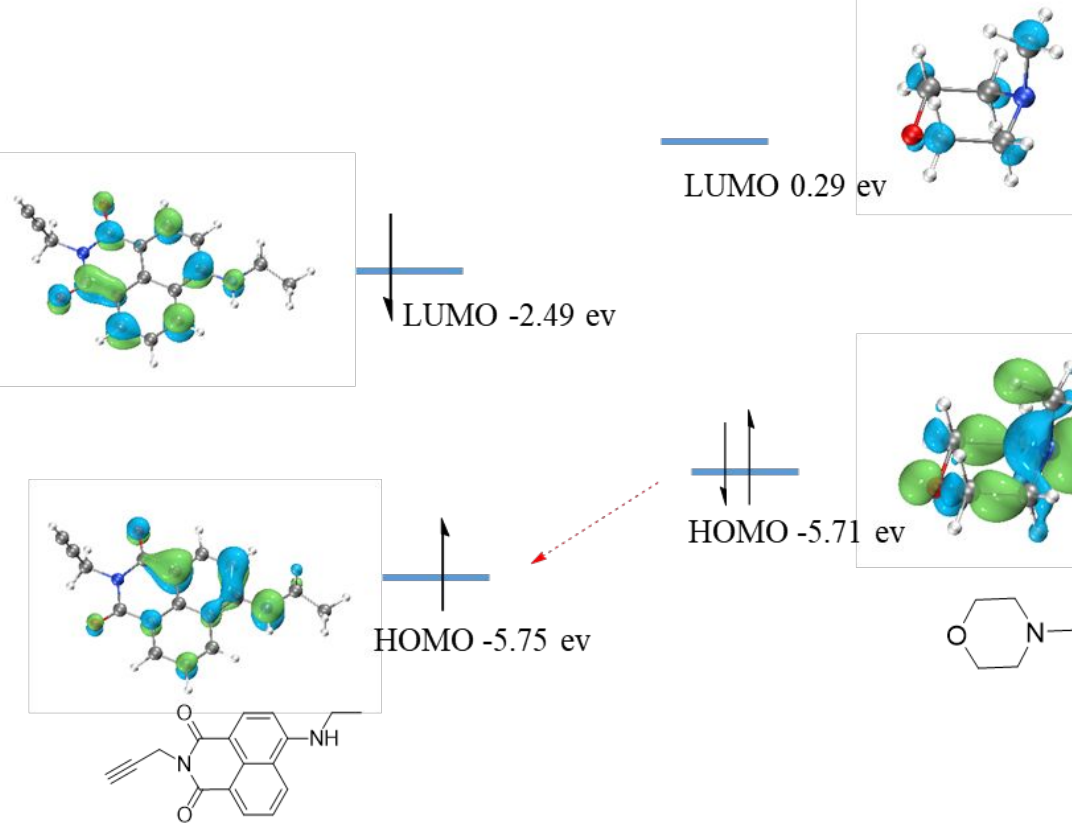

HOMO -5.71 ev

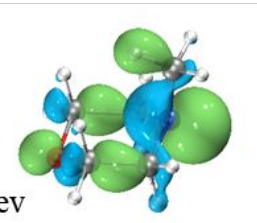

$\mathrm{O}^{\mathrm{N}}-$

Figure S10 The HOMO and LUMO of 4-ethylaminonaphthalimide chromophore and 4-methylmorphine calculated by Gaussian16, B3LYP, 6-311G(d). ${ }^{[1-3]}$

Table S1. The HOMO and LUMO orbitals of molecules calculated by Gaussian16, B3LYP, 6-311G(d).

\begin{tabular}{|l|l|l|}
\hline Molecules & HOMO orbital & LUMO orbital \\
\hline & & \\
\hline
\end{tabular}




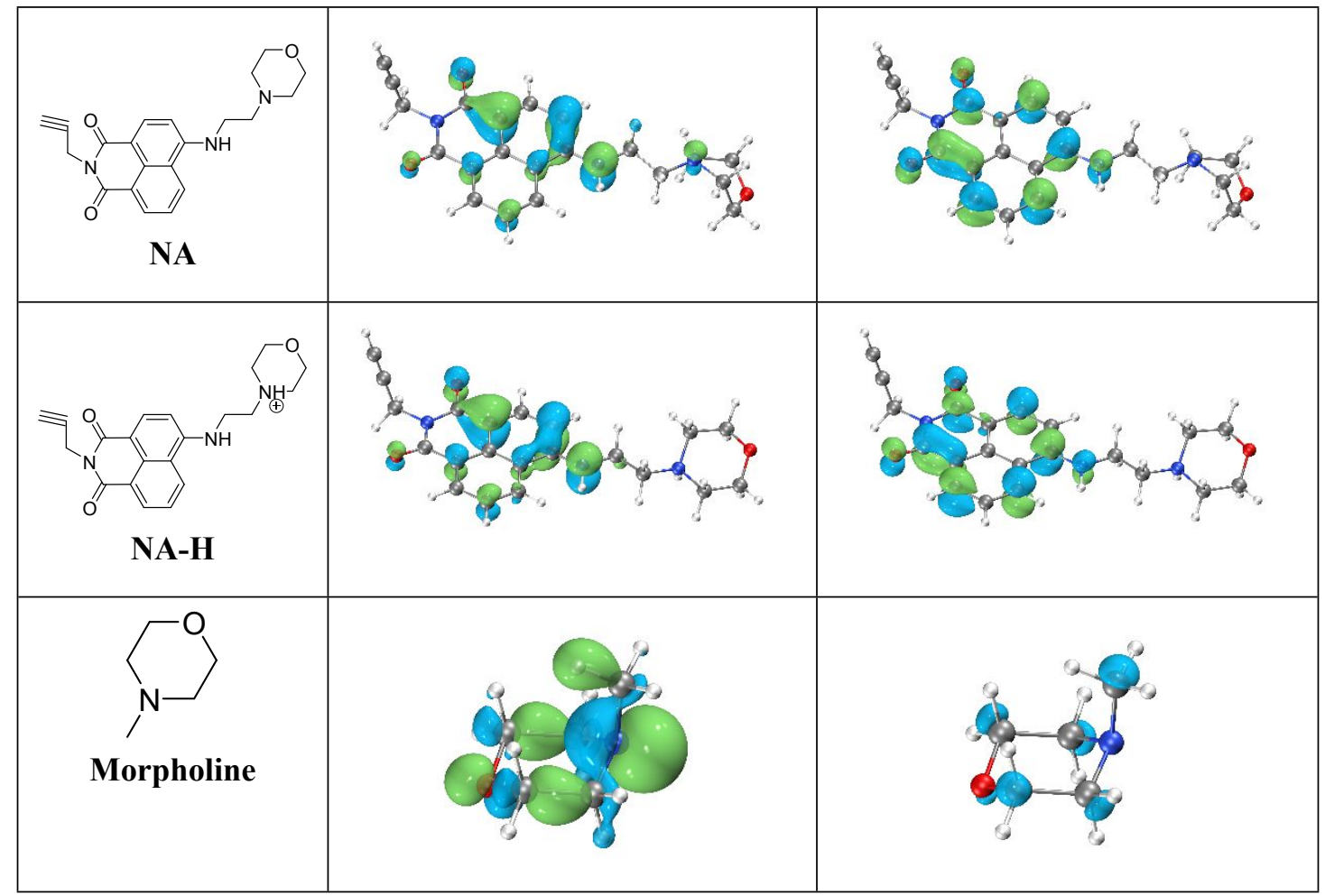

Table S2. The HOMO, LUMO orbitals energy and oscillator strength of molecules calculated by Gaussian16, B3LYP, 6-311G(d).

\begin{tabular}{|c|c|c|c|c|}
\hline Molecules & $\begin{array}{c}\text { HOMO } \\
\text { / ev }\end{array}$ & $\begin{array}{c}\text { LUMO } \\
\text { / ev }\end{array}$ & $\begin{array}{c}\text { HOMO-LUMO } \\
\text { Gap / ev }\end{array}$ & $\begin{array}{c}\text { Oscillator } \\
\text { strength }\end{array}$ \\
\hline RN & -5.70 & -3.04 & 2.66 & 0.877 \\
\hline RN-H & -5.87 & -3.25 & 2.62 & 1.0326 \\
\hline NA & -5.75 & -2.50 & 3.25 & 0.1516 \\
\hline NA-H & -5.89 & -2.56 & 3.32 & 0.2615 \\
\hline Morpholine & -5.71 & 0.29 & 6.00 & $-^{-a}$ \\
\hline
\end{tabular}

a The data were not calculated. 


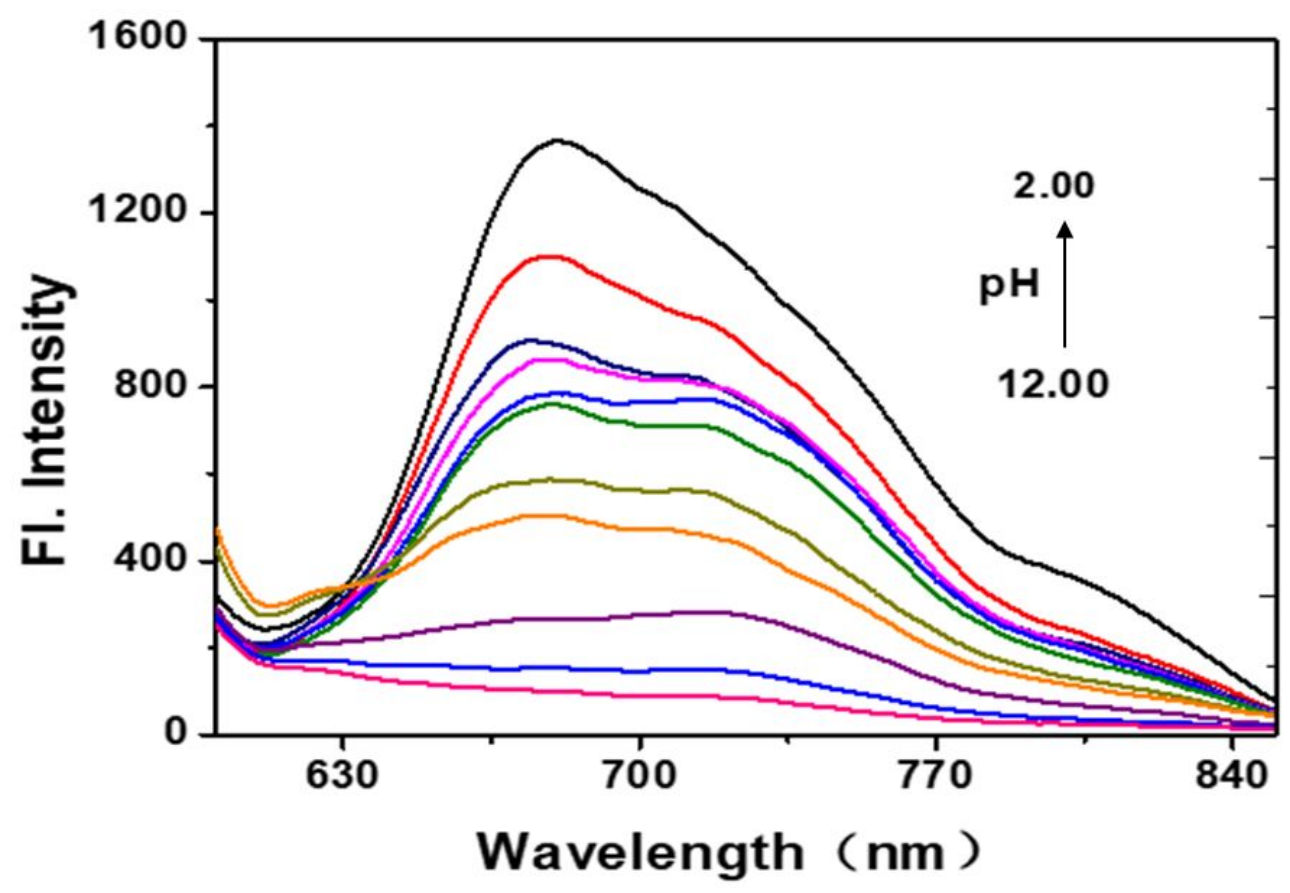

Figure S11 The emission spectra change of RN-NA in different $\mathrm{pH}$ values ( $\mathrm{pH}$ 2-12) solution. $10 \mu \mathrm{M}$ of RN-NA in $10 \mathrm{mM}$ of PBS with 5\% DMSO as cosolvent.

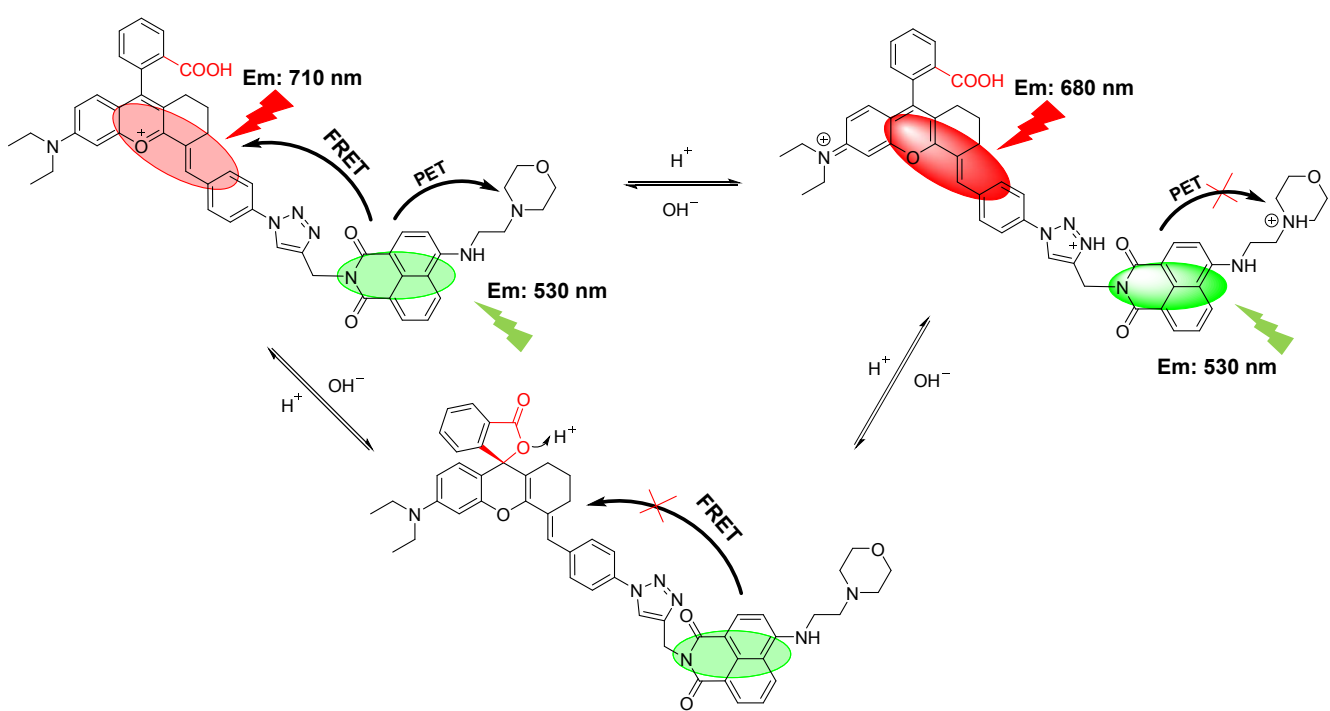

Figure S12 Fluorescence spectrometric change mechanism of RN-NA in different $\mathrm{pH}$ solution. 

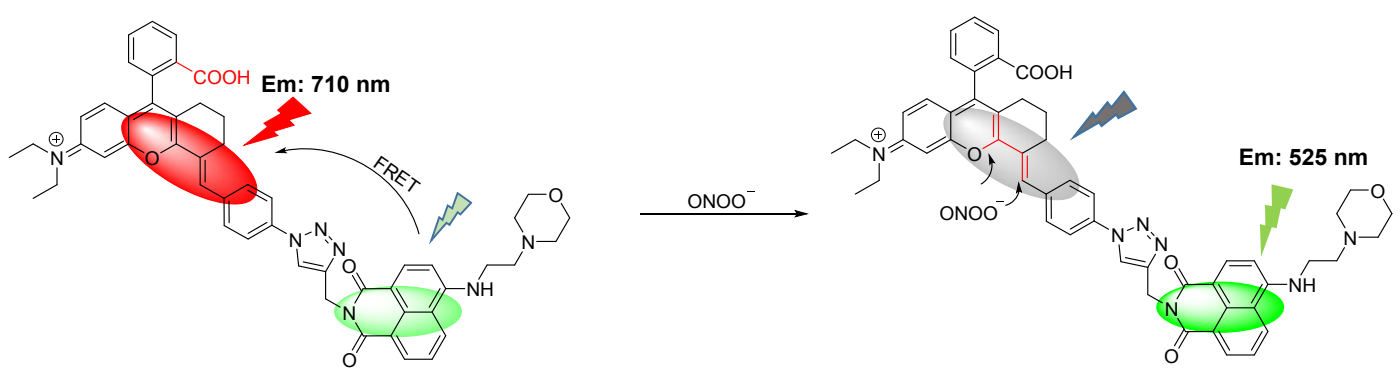

Figure S13 Probable fluorescence spectrometric change mechanism of RN-NA in the presence of $\mathrm{ONOO}^{-}$.

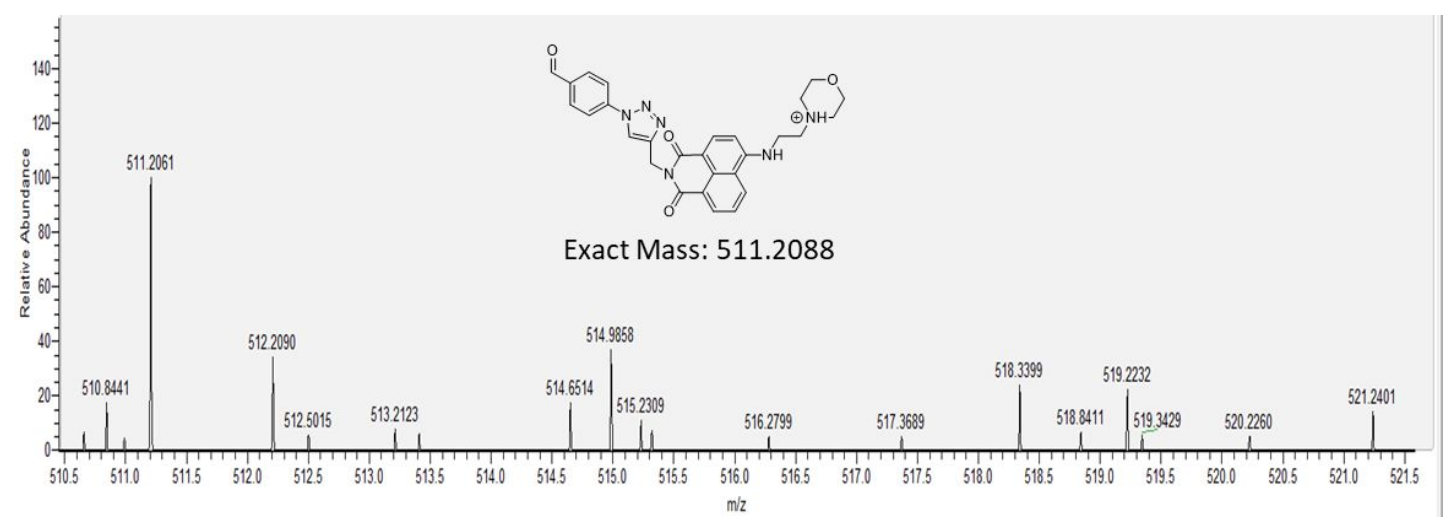

Figure S14 The HR-MS spectrum of compound RN-NA in the presence of excessive amount of $\mathrm{ONOO}^{-}$. 


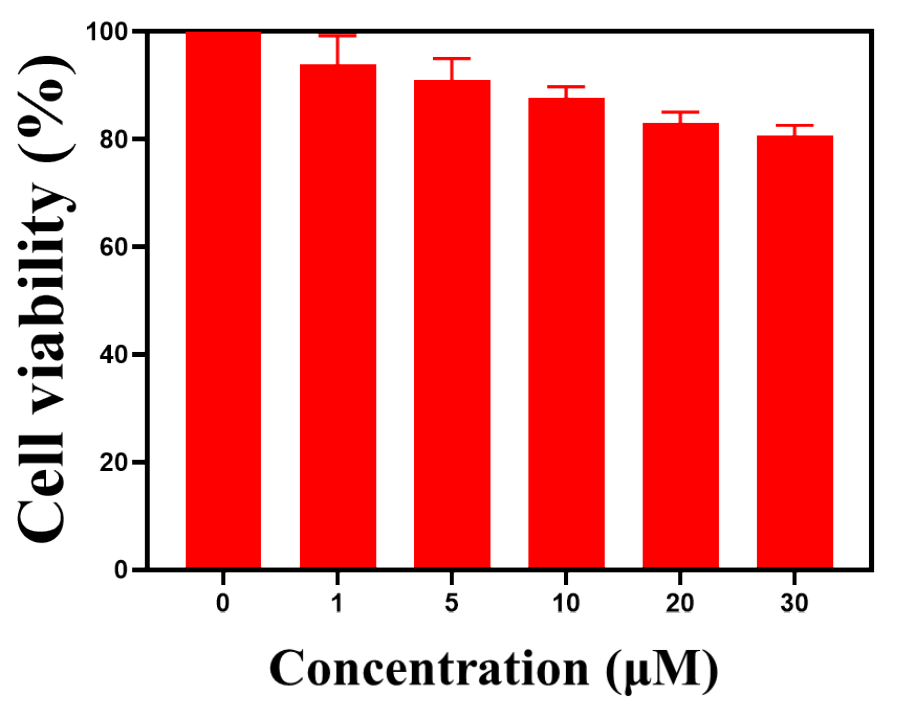

Figure S15 The MTT assay of RN-NA. $0 \mu \mathrm{M}, 1 \mu \mathrm{M}, 5 \mu \mathrm{M}, 10 \mu \mathrm{M}, 20 \mu \mathrm{M}, 30 \mu \mathrm{M}$ of RN-NA were added to HeLa cells, and the probe were incubated for $12 \mathrm{~h}$ before standard MTT assay.

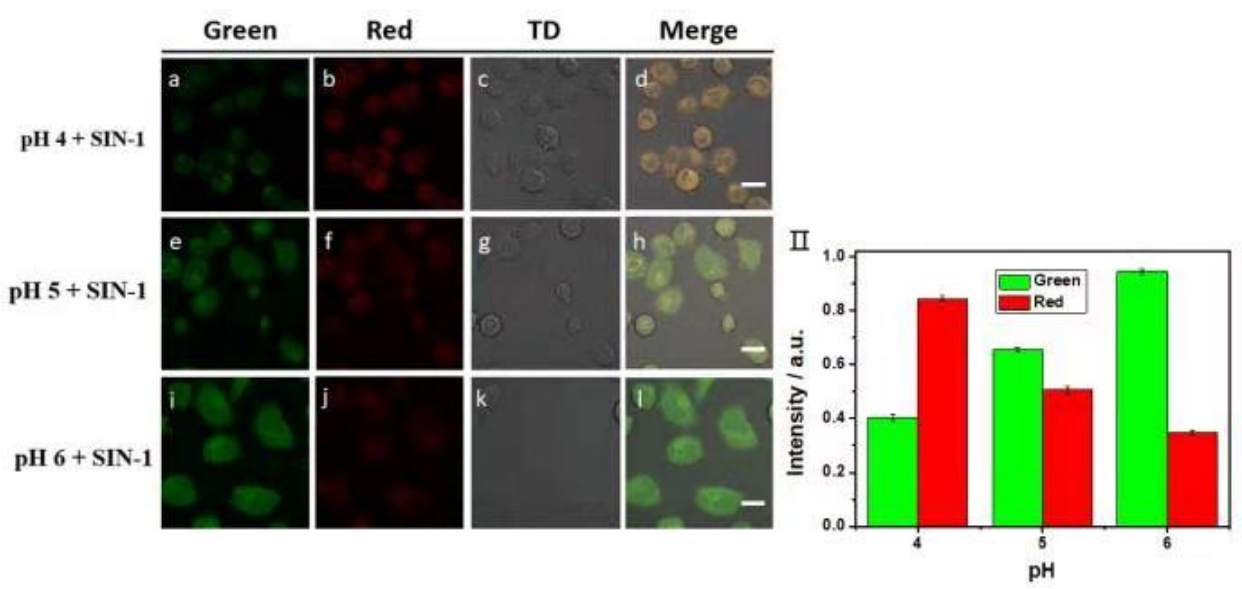

Figure S16. Fluorescence imaging stimulated by SIN-1 under different $\mathrm{pH}$ solution in HeLa cells. HeLa cells were cultured with high-potassium solution at different $\mathrm{pH}$ values and nigericin $(2 \mu \mathrm{g} / \mathrm{mL})$ and stimulated by SIN-1 $(30 \mu \mathrm{M})$ for $30 \mathrm{~min}$, followed by incubation with $10 \mu \mathrm{M} \mathbf{R N}-\mathbf{N A}$ for $30 \mathrm{~min}$, and then cells imaging was performed. Red channel: $\lambda \mathrm{ex}=633 \mathrm{~nm}$, collection: $650-750 \mathrm{~nm}$; green channel: $\lambda \mathrm{ex}=488 \mathrm{~nm}$, collection: 500-600 nm. (II) Histogram of fluorescence-intensity changes of red channel and green channel at different $\mathrm{pH}$ values; Error bar: $\mathrm{n}=3$, scale bar: $10 \mathrm{um}$. 


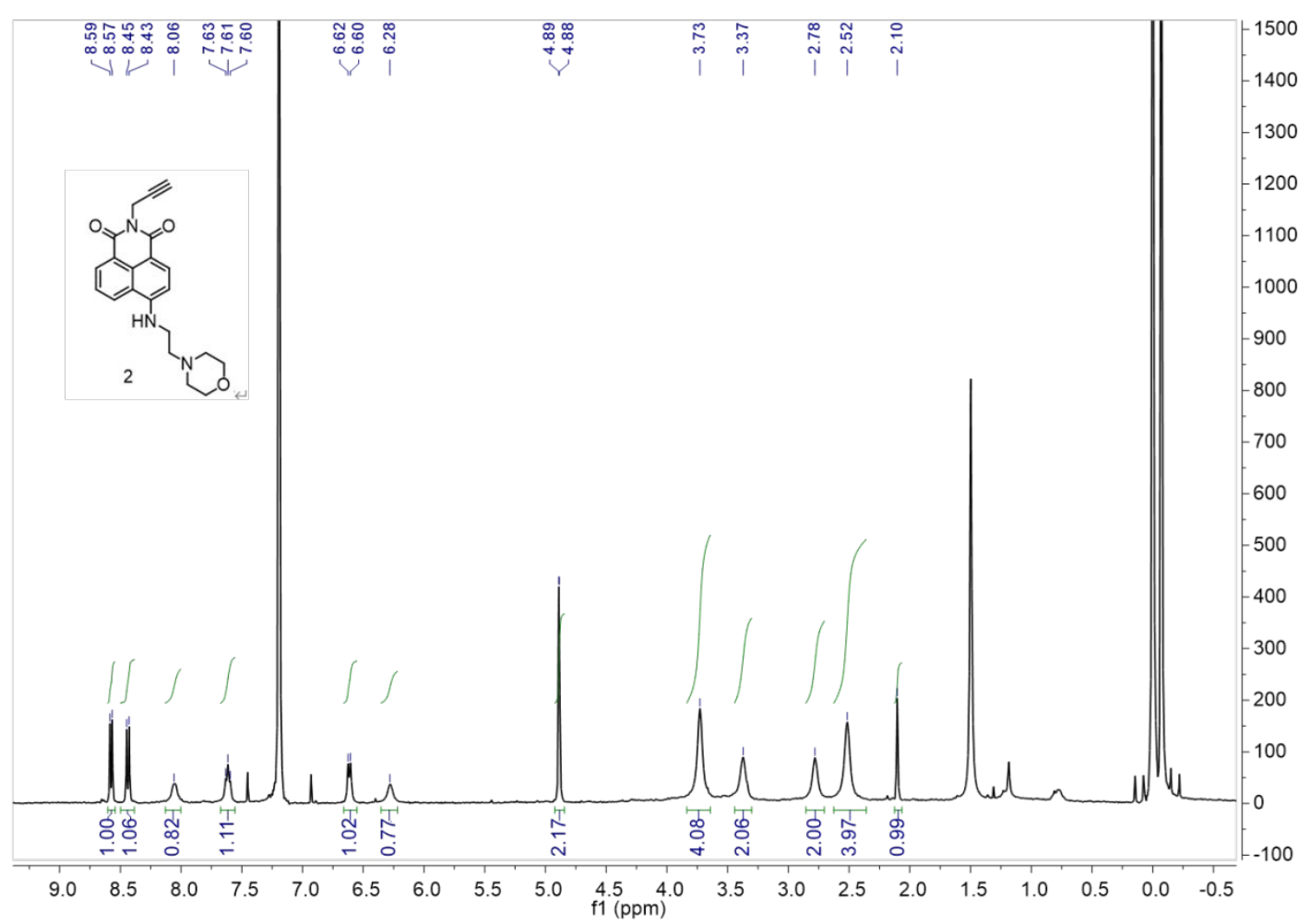

Figure S17 The ${ }^{1} \mathrm{H}$ NMR spectrum of compound $\mathbf{2}$ in $\mathrm{CCl}_{3} \mathrm{D}$.

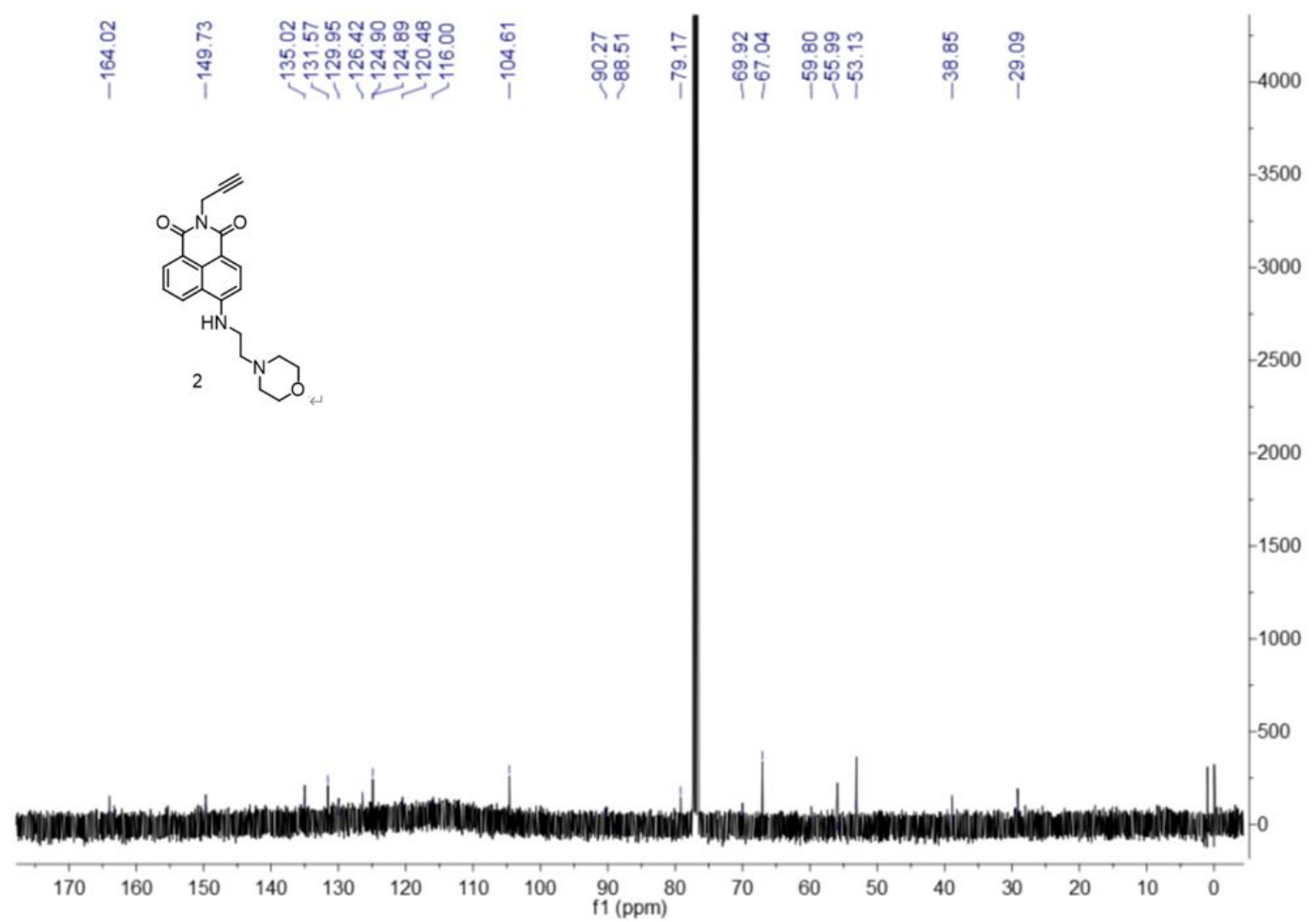

Figure S18 The ${ }^{13} \mathrm{C}$ NMR spectrum of compound 2 in $\mathrm{CCl}_{3} \mathrm{D}$. 


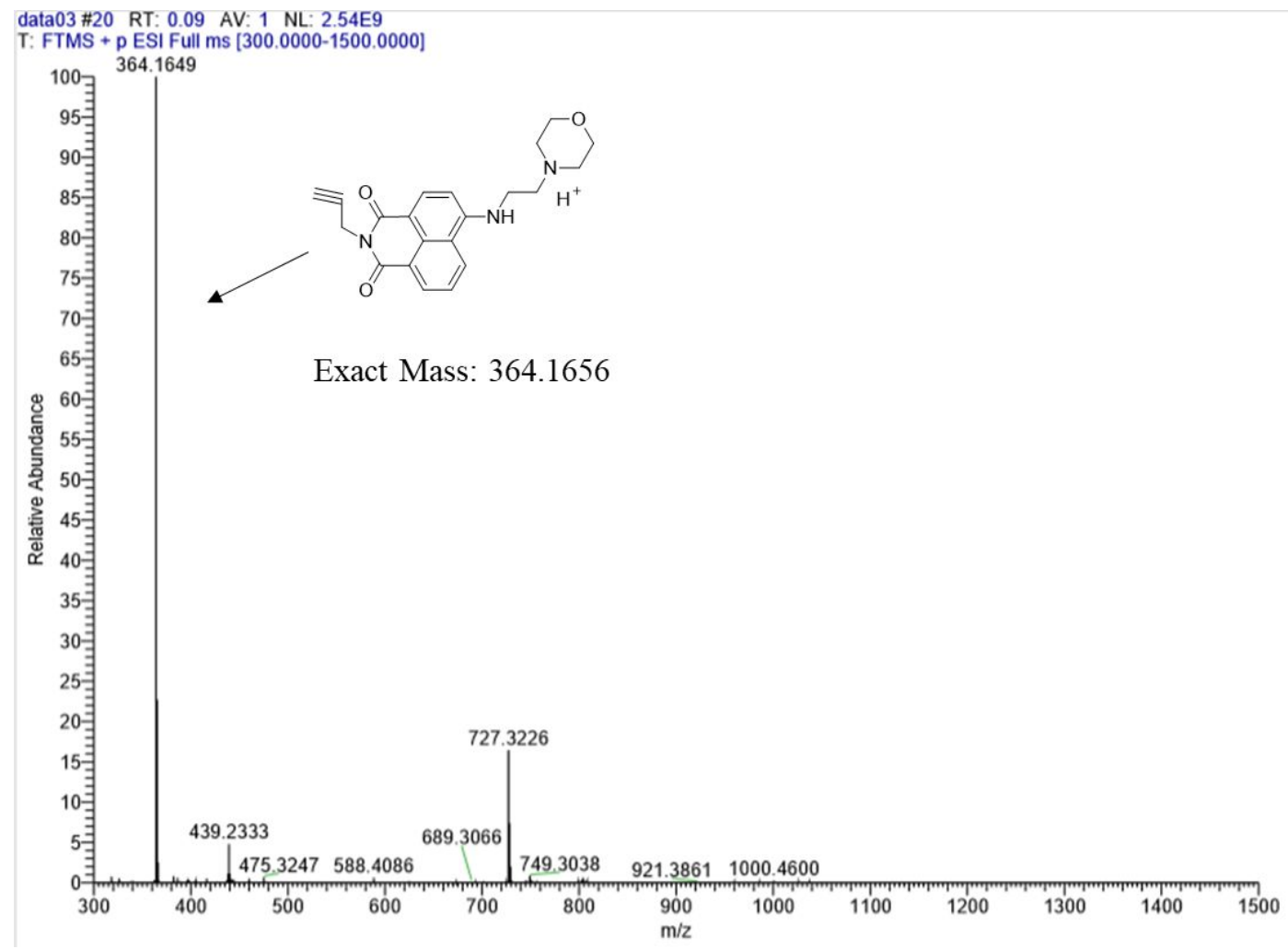

Figure S19 The HR-MS spectrum of compound 2.

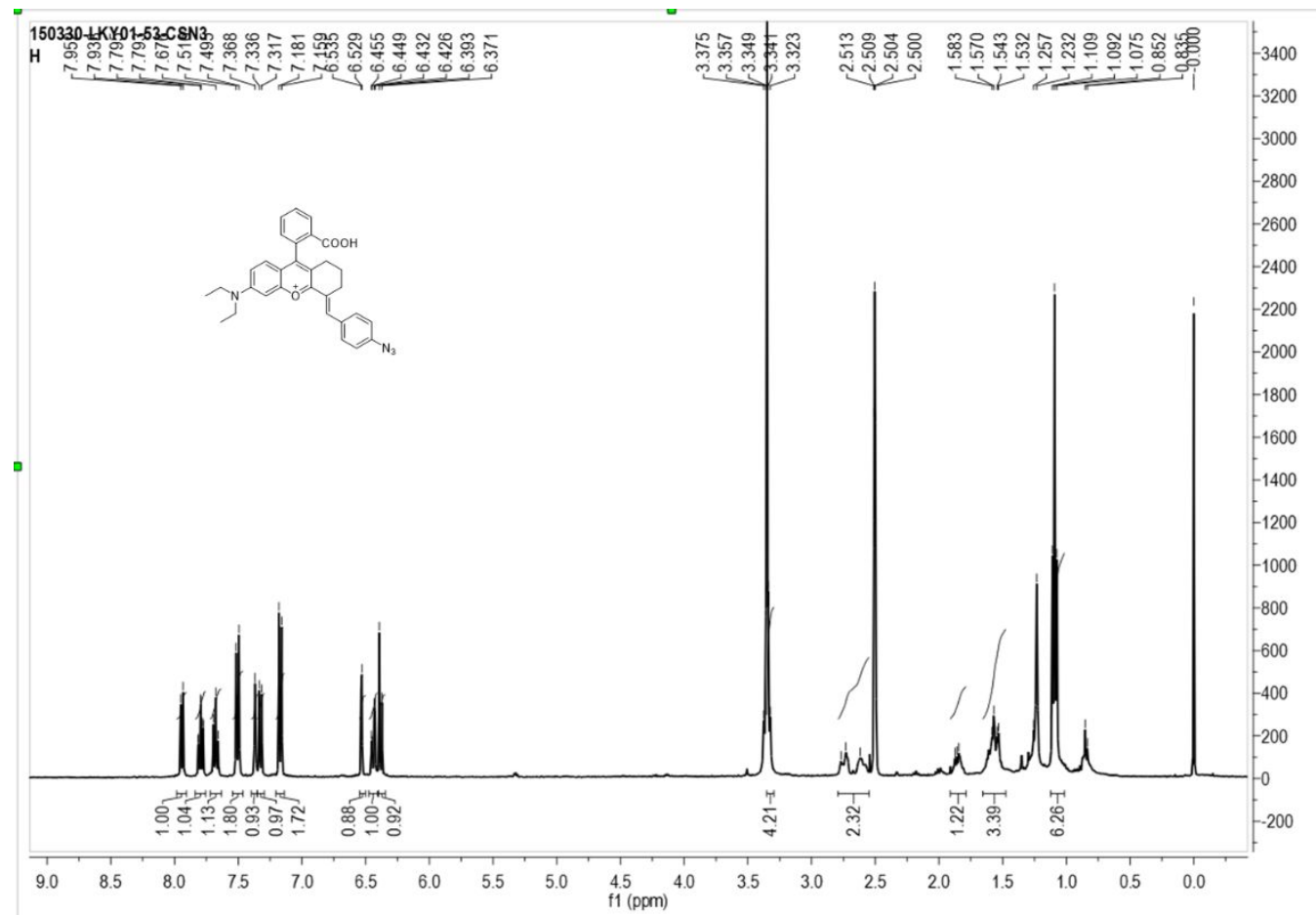

Figure S20 The ${ }^{1} \mathrm{H}$ NMR spectrum of compound 4 in DMSO- $\mathrm{d}_{6}$. 


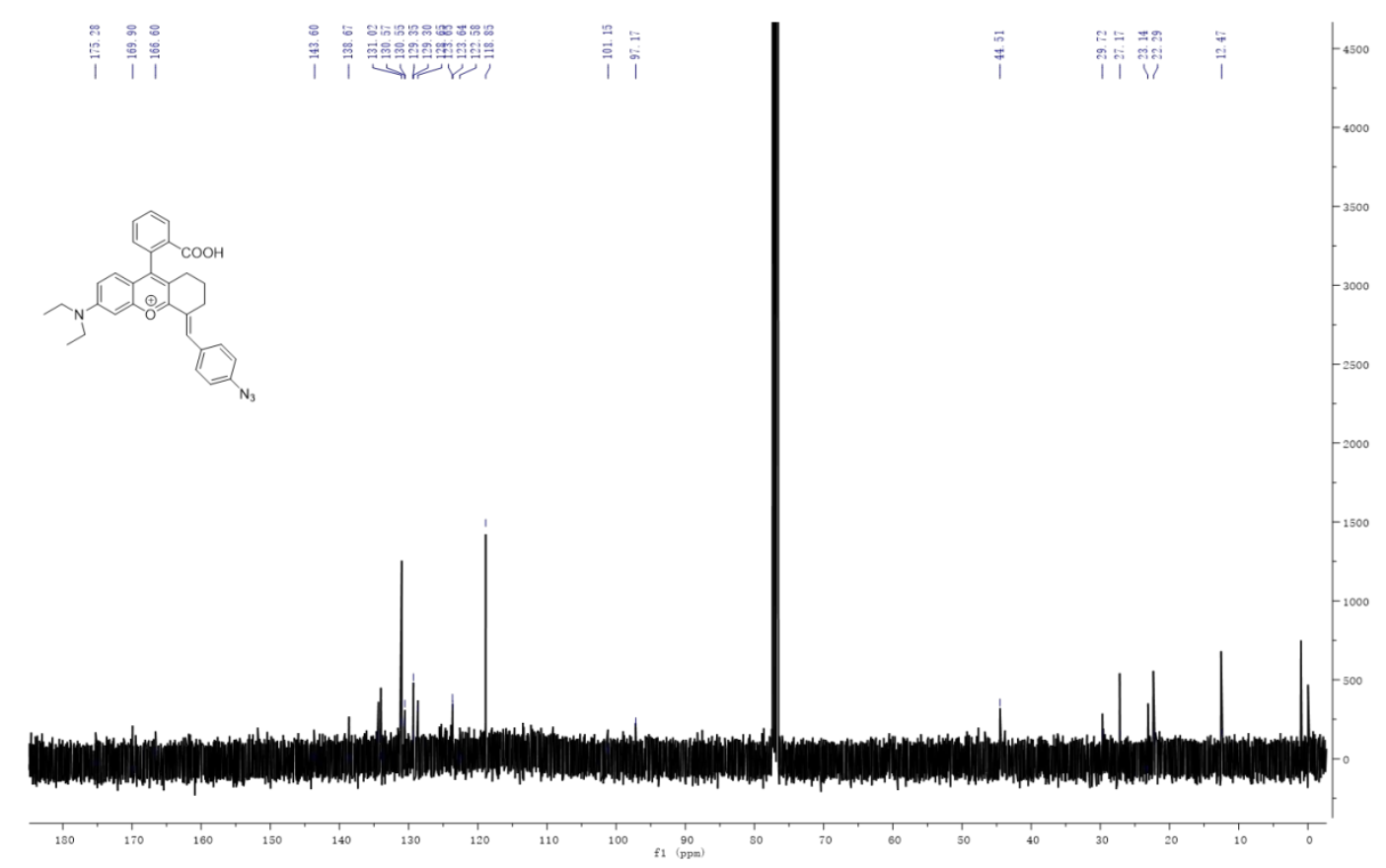

Figure S21 The ${ }^{13} \mathrm{C}$ NMR spectrum of compound 4 in DMSO-d 6 .

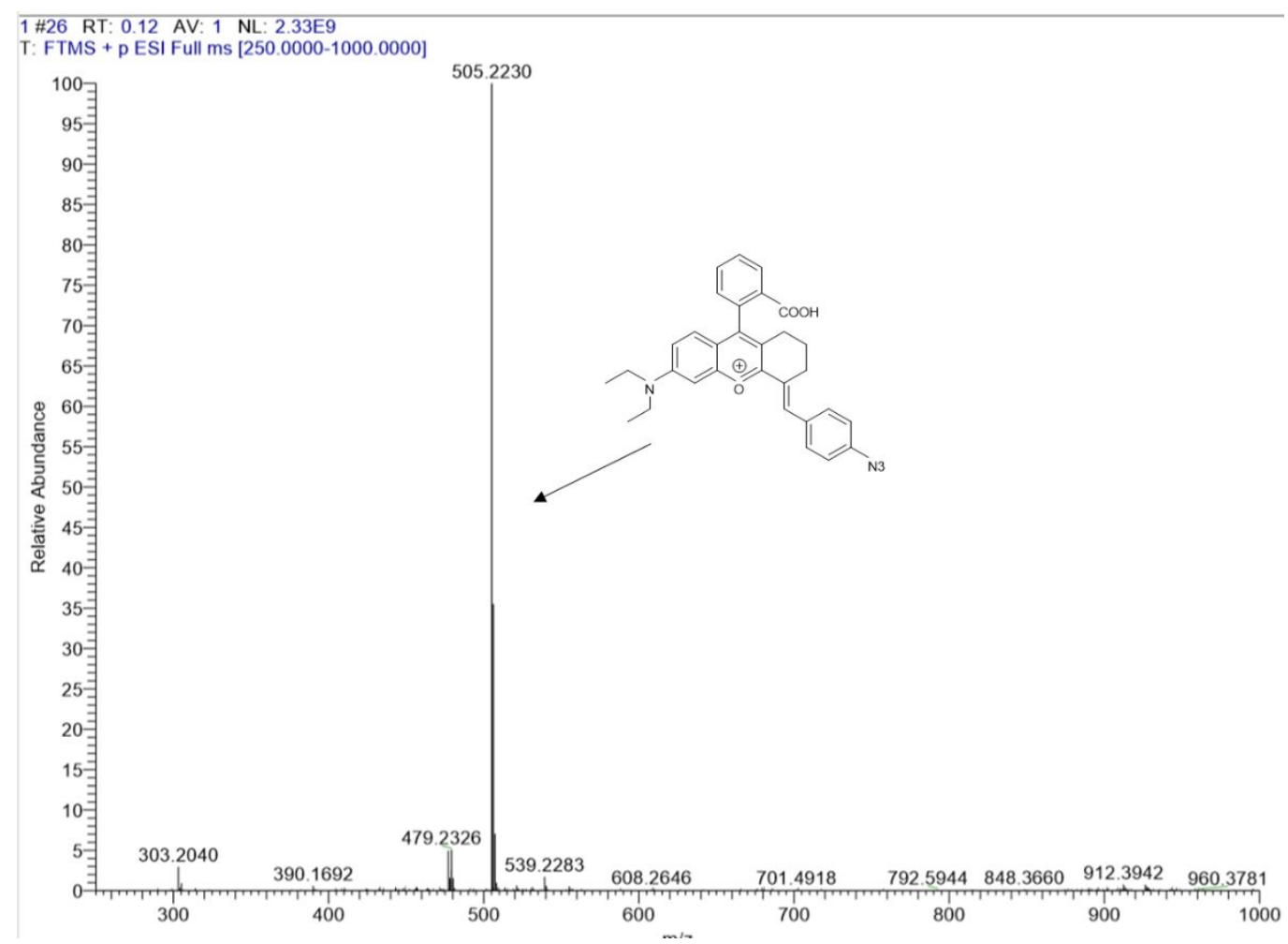

Figure S22 The HR-MS spectrum of compound 4. 


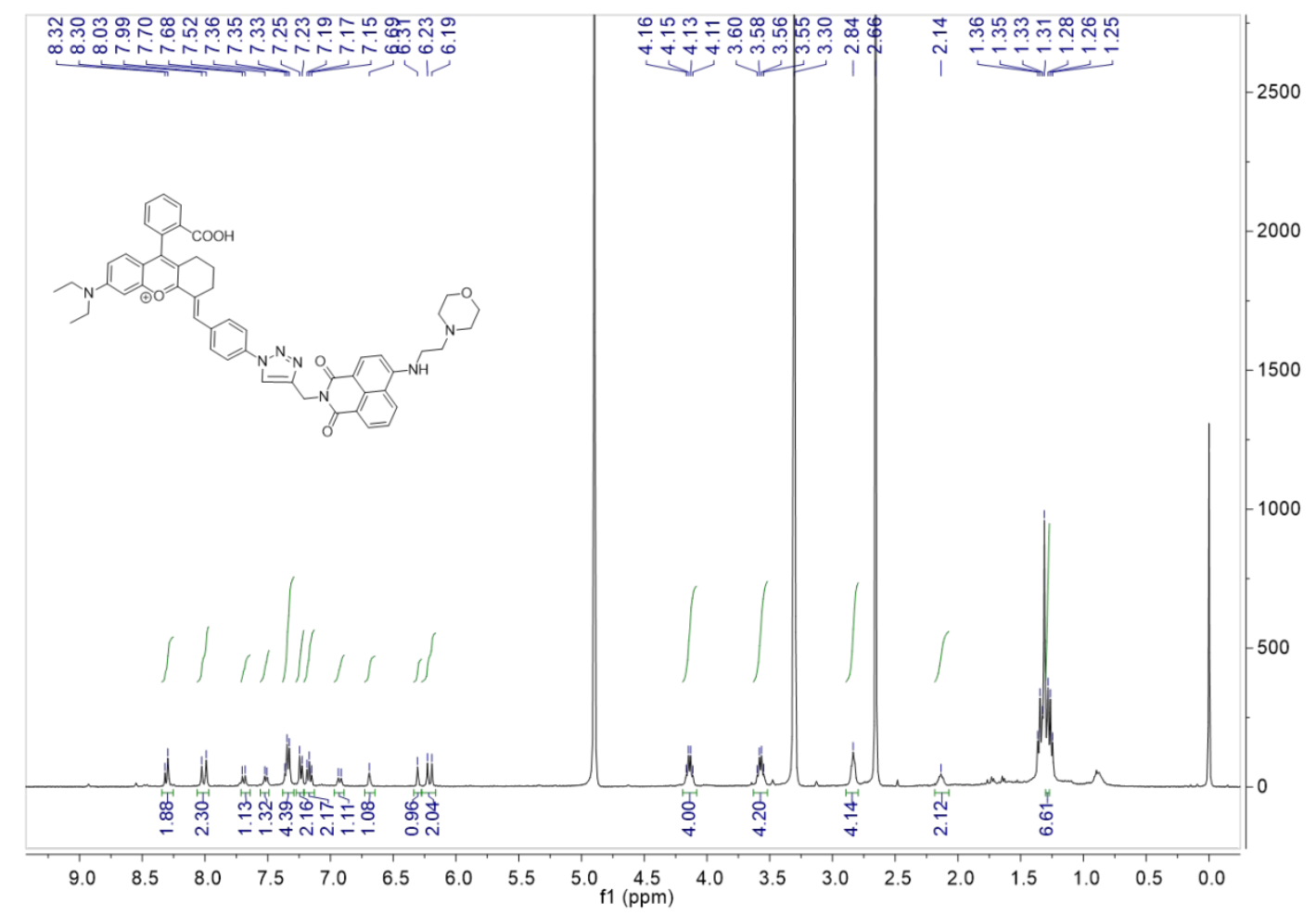

Figure S23 The ${ }^{1} \mathrm{H}$ NMR spectrum of RN-NA in MeOD- $\mathrm{d}_{3}$.

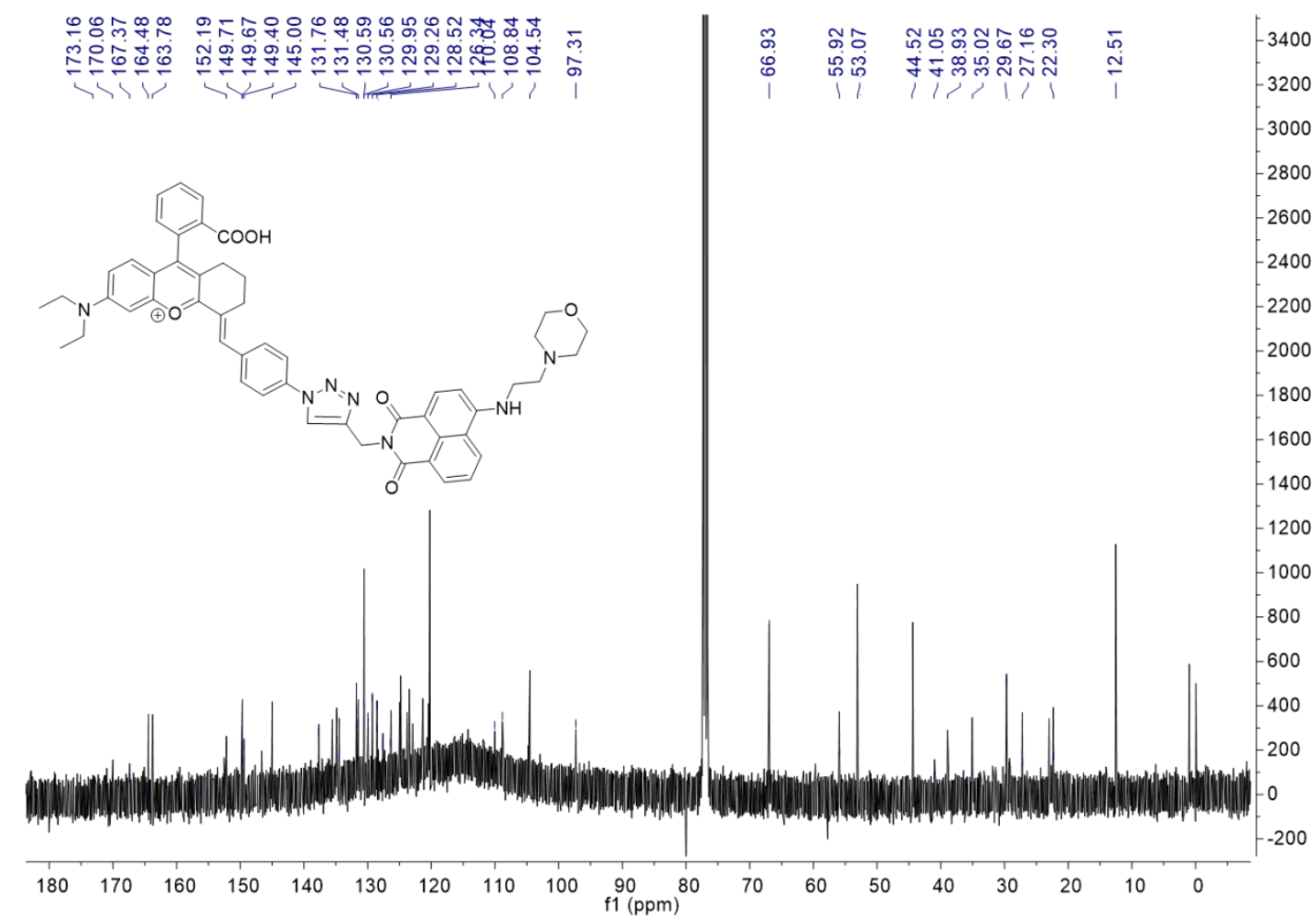

Figure S24 The ${ }^{13} \mathrm{C}$ NMR spectrum of RN-NA in MeOD- $\mathrm{d}_{3}$. 


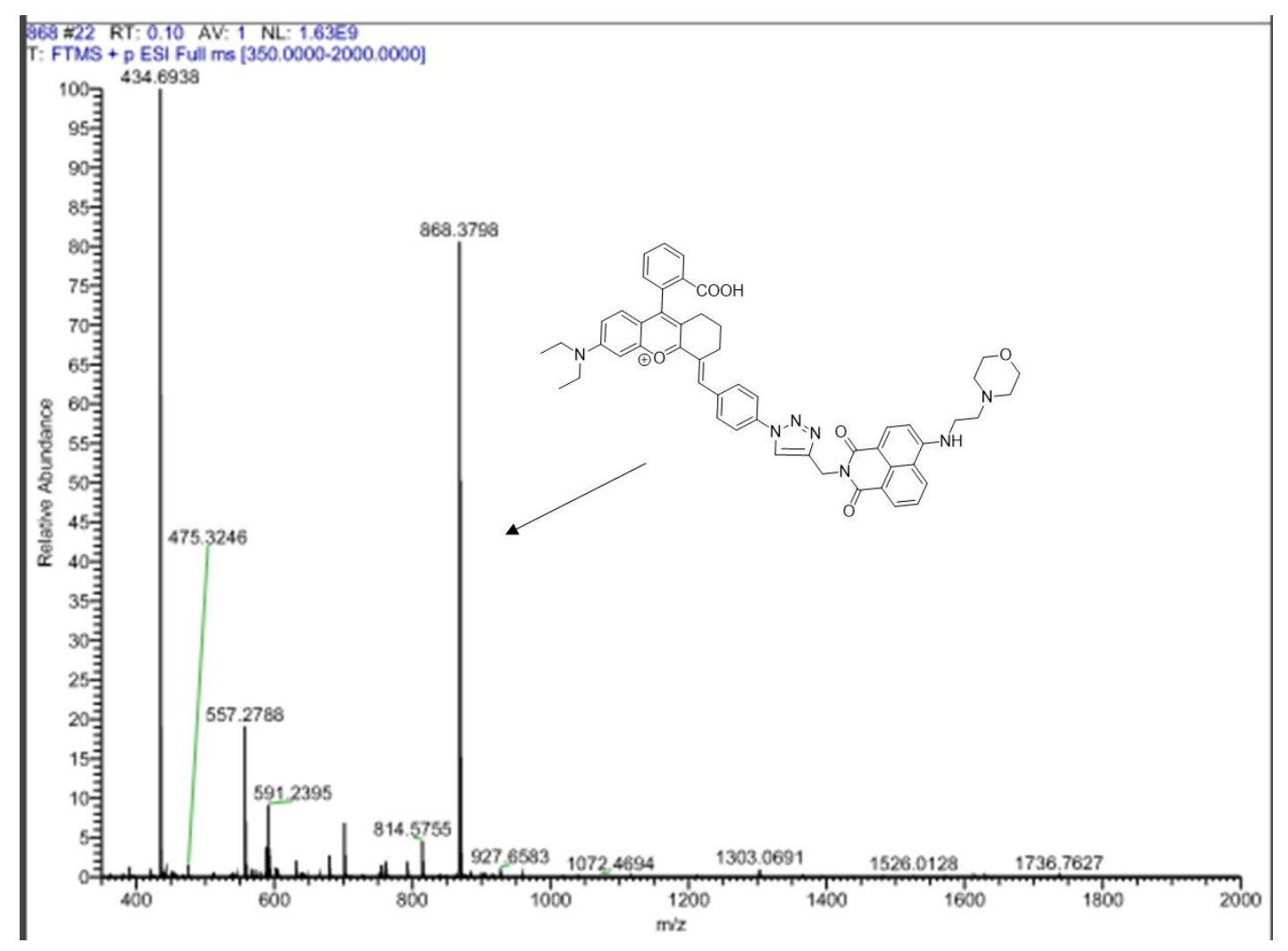

Figure S25 The HR-MS spectrum of RN-NA. 


\section{References}

(1) Dong, B.; Song, X.; Wang, C.; Kong, X.; Tang, Y.; Lin, W., Dual site-controlled and lysosome-targeted intramolecular charge transfer-photoinduced electron transferfluorescence resonance energy transfer fluorescent probe for monitoring $\mathrm{pH}$ changes in living cells. Anal. Chem. 2016, 88, 4085-4091.

(2) Dai, X.; Du, Z.-F.; Wang, L.-H.; Miao, J.-Y.; Zhao, B.-X., A quick response fluorescent probe based on coumarin and quinone for glutathione and its application in living cells. Analytica Chimica Acta 2016, 922, 64-70.

(3) Zheng, K.; Lin, W.; Tan, L.; Cheng, D., A two-photon fluorescent probe with a large turn-on signal for imaging hydrogen sulfide in living tissues. Analytica Chimica Acta 2015, 853, 548-554. 